\title{
Н.А. Зыкова
}

Пермский национальный исследовательский политехнический университет

ЗНАЧЕНИЕ МНОГОФУНКЦИОНАЛЬНОГО

МИГРАЦИОННОГО ЦЕНТРА В ОКАЗАНИИ

ГОСУДАРСТВЕННЫХ УСЛУГ ИНОСТРАННЫМ ГРАЖДАНАМ

В СФЕРЕ ТРУДОВОЙ МИГРАЦИИ В ПЕРМСКОМ КРАЕ

\begin{abstract}
Цифровые технологии постепенно становятся неотъемлемой частью жизни общества. В наше время трудно представить функционирование всех сфер жизни без помощи электронных, компьютерных, сетевых и множества других автоматизированных технологий. На сегодняшний день можно сказать, что ММЦ является ключевой площадкой цифровых технологий для трудовых мигрантов и работодателей в оказании государственных услуг в крае.

Ключевые слова: миграционная политика, международная миграция, трудовая миграция, цифровые технологии, миграционный центр, иностранный гражданин, патент.
\end{abstract}

На сегодняшний день процессы международной трудовой миграции в Пермской крае можно характеризовать двояко. С одной стороны, для международной миграции в этом регионе характерны проблемы общероссийского масштаба, которые во многом являются следствием действующего миграционного законодательства, а именно: нелегальная трудовая деятельность мигрантов, проблемы получения трудовых патентов, ограниченный доступ к медицинским услугам, языковой барьер. С другой стороны, наблюдаются региональные особенности, связанные, в первую очередь, с особенностями экономического развития региона, деятельностью органов местного самоуправления и частными инициативами. Для региона характерна достаточно масштабная организованная трудовая миграция по заказу крупных компаний, в том числе зарубежных, что в значительной степени облегчает для мигрантов процесс получения трудового патента и выполнение других необходимых формальностей. 
Иностранные граждане, желающие приехать в Россию для того, чтобы получить трудоустройство и оформиться на постоянное место жительства, обязаны обосновать цели своего приезда. При ином раскладе мигранты лишаются прав на официальное трудоустройство с возможностью получить должность. Данная поправка применяется и при безвизовом режиме. В том случае, когда целью является туристическая поездка, иностранец имеет реальную возможность получить патент и разрешение для устройства на работу.

Изучением непосредственно государственного регулирования трудовой миграции на современном этапе занимались Е.В. Тюрюканова [1], С.В. Рязанцев [2], В.И. Мукомель [3], И.В. Герасимова [4], П.А. Смелов, Е.А. Егорова [5], П.О. Дутов [6] и многие другие авторы.

Международная миграция хотя и не занимает лидирующие место в миграционных процессах Пермского края, тем не менее ощутимо влияет на формирование рынка труда. Развитие международной трудовой миграции должно происходить не только с учетом экономических факторов, но и обязательно должно поддерживаться мерами по интеграции мигрантов, а это предполагает открытое и конструктивное взаимодействие органов самоуправления, НКО, в том числе национальных общественных организаций и государственных структур [7, с.474].

В связи с введением ограничительных мер по предупреждению распространения коронавирусной инфекции и закрытии границ Российской Федерации для въезда и выезда иностранных граждан и лиц без гражданства, первое полугодие 2020 года характеризуется значительным снижением миграционных потоков и количества пребывающих иностранных граждан в Пермском крае. Основную долю среди иностранных граждан, прибывших в Пермский край, занимают граждане в возрасте 18-29 лет - 8024 (49,3 \%), в возрасте 30-39 лет - 3650 (22,4 \%), в возрасте 40-49 лет - 2184 (13,4\%), в возрасте 50-59 лет -1058 (6,5\%), 60 лет и более - $370(2,3 \%)$, в возрасте 17 и менее лет - 993 (6,1%). Таким образом, доля иностранных граждан трудо186 
способного возраста, находящихся в Пермском крае, составляет - 91,6\%. [8]. Среди находящихся иностранных граждан преобладают мужчины - 13049, что составляет 80,2\%. Доля женщин составляет - 19,8 \% (3230). Цели их временного пребывания на территории Пермского края обозначены в таблице 1.

Таблица 1

Цель въезда на территорию Пермского края временно пребывающих иностранных граждан ${ }^{1}$

\begin{tabular}{|l|c|}
\hline \multicolumn{1}{|c|}{ Цель въезда } & Количество \\
\hline Всего & 16279 \\
\hline Работа & $10681(65,6 \%)$ \\
\hline Частная & $2363(14,5 \%)$ \\
\hline Деловая & $48(0,3 \%)$ \\
\hline Туризм & $20(0,1 \%)$ \\
\hline Учеба & $3036(18,6)$ \\
\hline
\end{tabular}

Для улучшения качества оформления и получения патентов для трудовых мигрантов и работодателей в Пермском крае в 2019 году был создан Многофункциональный миграционный центр (далее ММЦ). Главная идея, которая реализовывалась при создании центра, заключалась в том, чтобы выстроить инфраструктуру получения мигрантом услуг по принципу «одного окна». Деятельность ГБУ Пермского края «Многофункциональный миграционный центр» полностью соответствует Концепции государственной миграционной политики Российской Федерации на период 2019-2025 гг., утвержденной указом Президента Российской Федерации[9].

В новом здании для иностранных граждан предоставляется весь комплекс услуг по оформлению патента на осуществление трудовой деятельно-

\footnotetext{
${ }^{1}$ Составлено автором на основе данных Управления по вопросам миграции ГУ МВД России по Пермскому краю.
} 
сти в Перми и Пермском крае. Во всех зонах ММЦ созданы системы обслуживания посетителей с новейшими современными технологиями.

Учреждение создано для оказания услуг по оформлению и выдаче иностранным гражданам патентов и других разрешительных документов для осуществления трудовой деятельности. В том числе ММЦ осуществляет прием заявлений и документов, необходимых для выдачи, продления срока действия или переоформления патента. В сфере оказания содействия в проведении обязательной дактилоскопической регистрации иностранных граждан, обращающихся за получением патента и их фотографировании, а также оказанию иностранным гражданам, прибывшим в Российскую Федерацию, консультационных услуг и услуг по проверке, заполнению документов.

Иностранный гражданин, приходя в ММЦ, сталкивается сразу с несколькими цифровыми технологиями. Новый многофункциональный миграционный центр площадью 2,5 тыс. кв. м состоит из семи функциональных зон. Его пропускная способность составляет 300 человек в сутки, что позволяет избежать образования очередей.

На сегодняшний день можно сказать, что ММЦ для трудовых мигрантов и работодателей является ключевой площадкой подготовки документов для осуществления трудовой деятельности на территории края, основанной на использовании цифровых технологий. В новом миграционном центре процесс приёма граждан и система оказания им услуг организованы современно и разумно. Здесь все предназначено для качественного приема данных от многочисленных гостей края, прибывающих сюда из стран ближнего зарубежья. Специалисты центра готовы принять документы, обработать их, проверить, проанализировать и подготовить нужные бумаги, например, патент, разрешающий мигрантам работать в России [10]. Хотя ММЦ Пермского края и включает в себя платформы цифровых технологий, но он не имеет своего официального сайта. Официальный сайт - информационный ресурс, являющийся неотьемлемой частью глобального распространения собственных товаров либо услуг. Официальный сайт проявляет себя как качественная 188 
единица информации в глобальной сети Интернет, поэтому каждый производитель или иное юридическое лицо представляет конечному пользователю только достоверную и полноценную информацию о товаре либо его услугах в более доступном и понятном виде. Отсутствие официального сайта центра затрудняет поиск необходимой и достоверной информации для иностранных граждан и работодателей, находящихся на территории края.

Анализируя информацию о ММЦ в субъектах ПФО и субъектахсоседях ПК можно сказать, что большинство субъектов не имеют ММЦ, а значит и не имеют своего официального сайта (рисунок 1).
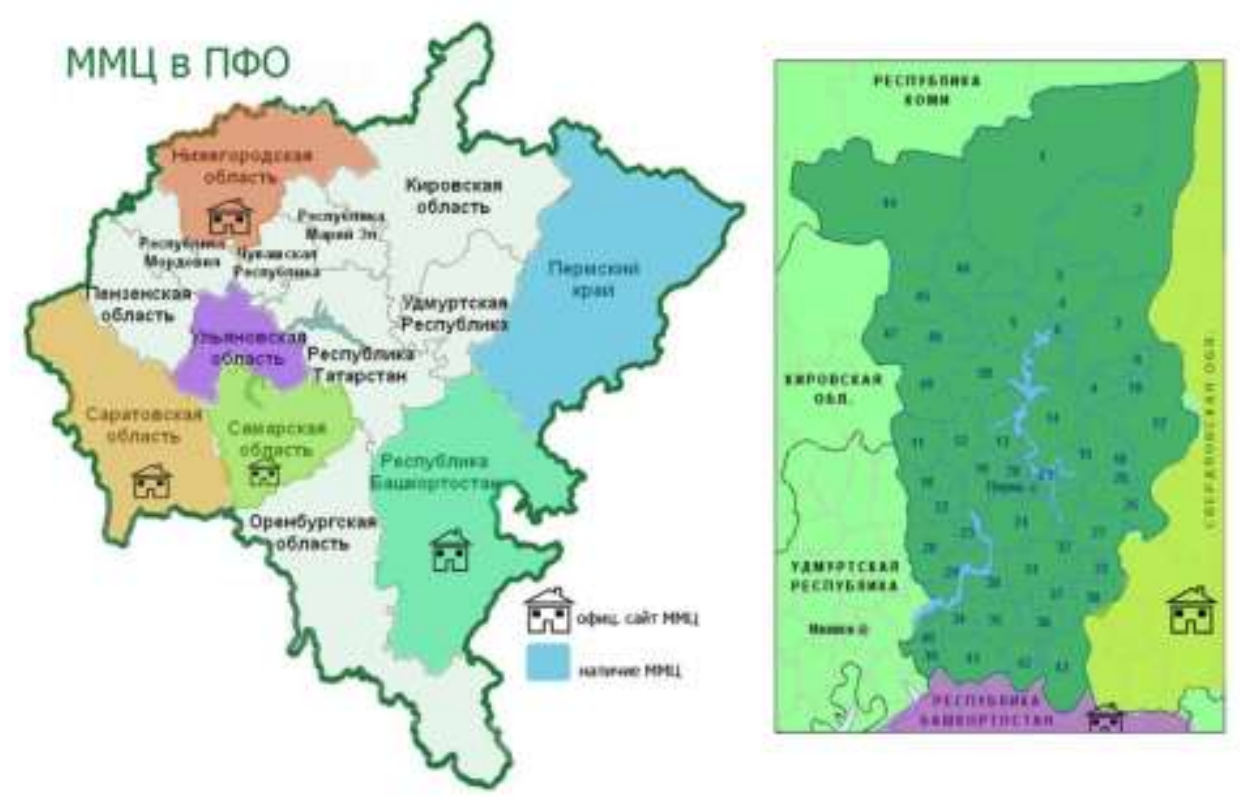

Рис.1. Многофункциональные миграционные центры в субъектах РФ Приволжского федерального округа

На территории ПФО только 6 субъектов из 14 имеют свой ММЦ (Пермский край, Нижегородская, Саратовская, Самарская и Ульяновская области, Республика Башкортостан), а наличие официальных сайтов центров из вышеуказанных субъектов есть только у 4 субъектов (Нижегородская, Саратовская и Самарская области, Республика Башкортостан). У соседей ПК 
только 2 субъекта имеют центр и свой официальный сайт (Свердловская область и Республика Башкортостан).

Собственный сайт ММЦ существенно повышает имидж компании в глазах потенциальных клиентов и партнеров. Сайт - это виртуальный офис, работающий круглосуточно и без выходных. В любой момент пользователь может зайти «в него» и получить нужную ему информацию: подробное описание получения услуг; контактные данные; время работы и т.д.

В связи с этим предлагается разработать официальный сайт ГБУ Пермского края «Многофункционального миграционного центра» для получения различных государственных услуг, в том числе продление и переоформление патента на работу. Через официальный сайт можно подать заявления на оформление патента, проверить его готовность, обратиться в службу поддержки ММЦ.

Некоторые тематические интернет ресурсы и программные комплексы представляют большой интерес и являются уникальными для исследователей в области миграционной политики.

Таким образом, развитие новейших систем и технологий оказывает большое влияние на совершенствование инструментов регулирования многих миграционных процессов. Создание официального сайта, станет еще одним шагом, в сторону повышения доступности и качества всех тех услуг, которые оказываются иностранным гражданам, прибывающим в Пермский край.

\section{Список литературы}

1. Тюрюканова Е.В. Гендер и экономика: мировой опыт и экспертиза российской : сб. статей / Отв. ред. и сост. Е. Б. Мезенцева. - М.: Русская панорама, 2002. - С. 71-87.

2. Щебланова В.В. Рецензия на: Рязанцев С.В. Влияние миграции на социально-экономическое развитие Европы: современные тенденции. 190 
Ставрополь: Кн. изд-во, 2001. 542 с.// Журнал исследований социальной политики. - 2003. - №2. - С. 280-282.

3. Мукомель В.И. Мигранты на российском рынке труда: занятость, мобильность, интенсивность и оплата труда // Статистика и Экономика. 2017. - №6. - С. 69-79.

4. Герасимова И.В. Разработка документов стратегического планирования, на примере государственных программ Российской Федерации / Сборник материалов Международной научно-практической конференции «Миграция и межнациональные отношения в современной России». М.: Литера, 2018. - С. 105-123.

5. Смелов П.А., Егорова Е.А., Изварина В.А. Трудовая миграция в Российской Федерации // Федерализм. - 2017. - № 3. - С. 149-160.

6. Дутов П.О. Внешняя трудовая миграция: к вопросу определения понятия и признаков // Вестник экономической безопасности. - 2018. - №3. C. 34-38.

7. Бородкина О.И., Лузянина Е.Г., Внутских А.Ю. Международная трудовая миграция в Пермском крае: проблемы и перспективы // Вестник Пермского университета. Философия. Психология. Социология. -2018. - № 3. - C. 474-483.

8. Управление по вопросам миграции ГУ МВД России по Пермскому краю [Электронный pecypc]. - URL: https://59.мвд.pф/gumvd/стркутура/подразделения-гу-мвд-россии-попермскому/управление-по-вопросам-миграции (дата обращения: 28.09.2020).

9. Указ Президента РФ от 31.10.2018 № 622 «О Концепции государственной миграционной политики Российской Федерации на 2019 - 2025 годы» [Электронный ресурс].

URL:http://www.garant.ru/products/ipo/prime/doc/70088244/ (дата обращения: 28.09.2020). 
10. Пермский городской портал Город 342 [Электронный ресурс]. URL:https://gorod342.ru/novosti/obschestvo/mvd-ocenili-potok-trudovyhmigrantov-v-permskom-krae.html (дата обращения: 28.09.2020).

N. A. Zykova

Perm National Research Polytechnic University

\section{HE IMPORTANCE OF A MULTIFUNCTIONAL MIGRATION CENTER IN PROVIDING PUBLIC SERVICES TO FOREIGN CITIZENS IN THE FIELD OF LABOR MIGRATION IN THE PERM REGION}

Digital technologies are gradually becoming an integral part of society. Nowadays, it is difficult to imagine the functioning of all spheres of life without the help of electronic, computer, network and many other automated technologies. Today we can say that the MMC is a key platform for digital technologies for migrant workers and employers in the provision of public services in the region.

Keywords: migration policy, international migration, labor migration, digital technologies, migration center, foreign citizen, patent. 